\title{
Beata Cytowska
}

Uniwersytet Wrocławski

\section{Dorosłość z perspektywy osób z głębszą niepełnosprawnością intelektualną w świetle zrealizowanych wywiadów pogłębionych}

Celem niniejszego artykułu i przedstawionych w nim badań jest ukazanie rozumienia przez osoby z głębszą niepełnosprawnością intelektualną (w stopniu umiarkowanym lub znacznym) swojej dorosłości, a także dociekanie ich refleksji nad dorosłością w ogóle przez pryzmat własnych doświadczeń. Podjęta problematyka stanowi wyzwanie dla współczesnej pedagogiki (nie tylko specjalnej) w związku ze stereotypem „wiecznych dzieci”, wciąż obciążającym proces dojrzewania wspomnianej grupy społecznej. Przedstawione w tekście badania miały charakter jakościowy i zrealizowane zostały zgodnie ze strategią konstruktywistycznej teorii ugruntowanej. Materiał zebrany został za pomocą wywiadów pogłębionych (z 27 osobami - 13 kobietami i 14 mężczyznami). Kodowanie, a następnie analiza i interpretacja otrzymanych danych wskazały, że badani dostrzegają swoją dorosłość i mówią o niej, jednak raczej o jej obiektywnych przejawach, odnosząc je do społecznie określonego wizerunku dorosłego człowieka. Trudniej im konstruować subiektywny obraz swojej dorosłości oparty na analizie doświadczania własnej dojrzałości do działań i zachowań świadczących o osiągnięciu dorosłości, takich jak odpowiedzialność, samostanowienie, podejmowanie decyzji.

Słowa kluczowe: dorosłość, niepełnosprawność intelektualna, dojrzałość, kobieta, mężczyzna

\section{Adulthood from the perspective of people with moderate to severe intellectual disability in the light of completed in-depth interviews}

The aim of this article and the presented study is to illustrate an understanding of adulthood by people with moderate to severe intellectual disability, as well as their reflections on a concept of adulthood through the prism of their own experiences. Mentioned issues represent a challenge for contemporary pedagogy (not only special education) due to the "eternal children" stereotype, which still concerns the maturing process of this social group. The presented qualitative research has been carried out by the constructivist grounded theory approach. The research material has been collected using in-depth interviews with 27 persons - 13 women and 14 men. Coding, analysis and interpretation of the data indicated that respondents recognize their adulthood and are able to talk about it, but they are more inclined to talk about its objective indicators and to relate them to the socially constructed adult human image. It is more difficult for them to create a subjec- 
tive picture of their own adulthood based on an analysis of their maturity to behaviour that is associated with the concept, such as responsibility, self-determination and making decisions.

Keywords: adulthood, intellectual disability, maturity, woman, man

\section{Wprowadzenie}

Dorosłość jest etapem rozwoju osobowościowego i społecznego człowieka, do którego zmierzają wszyscy ludzie. Zwykle jest pozytywnie wartościowana, pożądana, wyznaczana przez autorytety, ale też usankcjonowana przez normy społeczne. I choć przejście z wcześniejszego stadium - młodzieńczości - do dorosłości jest płynne i stanowi pewien proces, to jednostka empirycznie stwierdza jej jakościową odmienność (Malewski 2013; Tyndall i in. 2016).

Różnice można dostrzec we wszystkich sferach życia. Człowiek zmienia się fizycznie, dojrzewa płciowo, czego wyznacznikiem jest biologiczna gotowość do prokreacji. Dochodzi do integracji jego osobowości oraz ukształtowania tożsamości i światopoglądu, dzięki czemu staje się odpowiedzialny za siebie, może podejmować odpowiedzialność za drugiego człowieka, potrafi zapanować nad swoimi emocjami, radzi sobie w sytuacjach trudnych, ma gotowość do samostanowienia i decydowania o sobie. Z psychologicznego punktu widzenia najistotniejszym wyznacznikiem dorosłości jest umiejętność zaspokajania wszystkich potrzeb, a szczególnie tych wyższego rzędu, co umożliwia uzyskanie pełnej samodzielności i niezależności.

Społeczne atrybuty dorosłości wyznaczane są przez zdolności jednostki do podjęcia pracy zarobkowej, pełnienia ról społecznych, co wymaga od niej ukształtowania poczucia obowiązku oraz rozumienia zasad i norm społecznych.

Z perspektywy kulturowej dorosłość wiąże się z gotowością do kultywowania tradycji i jej przekazu kolejnym pokoleniom. Symbolicznie określna jest przez szereg rytuałów (tzw. ceremonie „przejścia”). W naszej kulturze są to np.: matura i bal maturalny, "osiemnastka”, bierzmowanie związane z religią katolicką (Brzezińska i in. 2011; Dubas 2005; Pichalski 2003; Oleś 2011; Settersten i in. 2015).

Elżbieta Dubas (2005) uważa, że istotę złożoności pojęcia dorosłości dobrze oddają trzy jej modele: statyczny, dynamiczny i ponowoczesny. Pierwszy, opisuje dorosłość jako obiektywną rolę społeczną i wynik socjalizacji. Drugi, ujmuje dorosłość w kategorii całożyciowego procesu stawania się dorosłym. Dorosłość stanowi więc swoistą wartość, sprzyja osiąganiu innych wartości. Ma przede wszystkim wymiar subiektywny. Model ponowoczesny zaś ujawnia dorosłość jako zjawisko względne, ambiwalentne. Zgodnie z cechami życia człowieka w kulturze ponowoczesnej, jest zagubiona, zmienna, skazana na siebie, osamotniona, 
poszukująca, mozaikowa - fragmentaryczna i niepełna, niezakończona, zmienna, zróżnicowana i zindywidualizowana (Glanc 2011).

Zatem dorosłość można rozpatrywać w wymiarze subiektywnym i obiektywnym, statycznie jako stan - osiągnięty cel życiowy (bycie dorosłym w subiektywnym odczuciu) lub cel, do którego jednostka dąży w swoim rozwoju (przyjęty obiektywny - wzór dorosłości) oraz dynamicznie, jako proces stawania się dorosłym - dojrzewania do dorosłości. Na te wymiary nakładają się postrzegania jednostkowe i społeczne dorosłości. Jednostka może odbierać swoją dorosłość jako dojrzałość do realizacji zadań dorosłego człowieka (także przez porównywanie się z innymi dorosłymi); społecznie dorosłość jest określana jako konstrukt społeczno-kulturowy służący za narzędzie dyscyplinujące jednostkę - wyznacza jej cele w rozwoju oraz normy, zgodnie z którymi będzie wartościowana. Współcześnie, niezależnie od tego, czy dorosłość rozpatrujemy jako stan, czy jako proces, subiektywnie wartościowany przez jednostkę, czy obiektywnie - przez społeczeństwo, ma ona wszystkie, wspomniane wyżej, cechy ponowoczesności.

Dodać należy, że niepełnosprawność intelektualna (NI) jest tylko jednym z czynników komplikujących dojrzewanie do dorosłości i jej przebieg (zob. Strnadova, Evans 2012).

Podjęta w tekście problematyka dotyczy dorosłości osób z głębszą NI. Do niedawna zainteresowania tą populacją nie wykraczały poza okres wczesnej dorosłości, który wiąże się jeszcze z jej edukacją szkolną․ Co można tłumaczyć ograniczoną długością życia - współcześnie wiek przeżywania osób z głębszą NI wydłuża się, głównie dzięki rozwojowi opieki medycznej (zob. Martin i in. 2017); a z drugiej strony wyjaśnia to wciąż aktualny brak perspektyw społecznych i zawodowych dla dorosłych i starzejących się osób, których funkcjonowanie intelektualne pozostaje co najwyżej na poziomie wczesnomłodzieńczym (wczesnej adolescencji). Jednak obowiązujący dziś biopsychospołeczny model niepełnosprawności kładzie nacisk na rozpatrywanie trudności doświadczanych przez osoby z niepełnosprawnością intelektualną z perspektywy ograniczeń wynikających z barier środowiskowych, prawnych, kulturowych, a nie sytuowanie ich $\mathrm{w}$ problemach stanowiących o diagnozowaniu niepełnosprawności u danej osoby. (Gąciarz 2017) Badania wskazują, że orzeczenie niepełnosprawności u jednostki nie wyznacza jej ograniczeń, konstytuuje je dopiero otoczenie - bliskie i dalsze, materialne i niematerialne. Dostrzeganie społecznych uwarunkowań NI uzmysłowiło wielość błędów popełnianych $w$ traktowaniu dorosłych oraz starzejących się kobiet i mężczyzn z głębszą NI: infantylizowanie ich potrzeb, mar-

\footnotetext{
Zgodnie z rozporządzeniem MEN z dnia 9 sierpnia 2017 r. w sprawie warunków organizowania kształcenia, wychowania i opieki dla dzieci i młodzieży niepełnosprawnych, niedostosowanych społecznie i zagrożonych niedostosowaniem społecznym, osoby z niepełnosprawnościami mogą być objęte edukacją do 24 roku życia (§ 4, pkt 2, Dz. U. z 2017 r., poz. 1578).
} 
nowanie potencjału, zaprzeczanie możliwości podejmowania ról społecznych to tylko niektóre zaniechania wobec tej grupy (Cytowska 2012; Kijak 2017; Krzemińska, Lindyberg 2012; Woynarowska 2010; Żyta 2011).

Współcześnie zmienia się podejście do rozpatrywanej populacji. Praktyka i empiria potwierdzają, że niwelowanie barier społecznych albo pomoc $w$ ich pokonywaniu, sprawiają, że otwiera się rynek pracy dostrzegający potencjał pracowniczy tych osób; rozwijają się formy ułatwiające im korzystanie z dóbr kultury, ale też czynne uczestnictwo $w$ ich tworzeniu; zmienia się myślenie o ich seksualności i potrzebach z nią związanych. (por. Głodkowska 2014).

W Polsce niestety brakuje systemowych rozwiązań, które sprzyjałyby większej autonomii osób z NI, takich jak zamieszkanie poza rodziną (ale nie w instytucjach typu DPS), jednak projektowe przedsięwzięcia ukazują przykłady korzystnych rozwiązań podnoszących jakość życia rozpatrywanej grupy społecznej (zob. Gołubiew-Konieczna 2016).

Dorosłość osób z NI, uwikłana w skomplikowany kontekst psychospołeczny, stanowi interesujący przedmiot badań. Dodatkowo postawienie sobie za cel zbadanie jej z perspektywy dorosłych kobiet i mężczyzn z głębszą NI- jako własnych doświadczeń, ale także dociekanie ich refleksji nad dorosłością w ogóle przez pryzmat tych doświadczeń, wydaje się być ważnym i potrzebnym przedsięwzięciem naukowo-badawczym.

\section{Podstawy metodologiczne badań własnych}

$\mathrm{W}$ ostatnich latach pojawiły się liczne doniesienia z badań prowadzonych w Polsce nad dorosłymi osobami z głębszą NI (w stopniu umiarkowanym lub znacznym). Można je podzielić na te, które dotyczą wspomnianej grupy, ale bez ich udziału (np. Parchomiuk 2016; Rękosiewicz 2012; Zasępa 2017) i te, w których osoby z NI osobiście uczestniczą (np. Cytowska 2012; Kijak 2017; Krzemińska, Lindyberg 2012; Żyta 2011).

Badania ukazane w niniejszym opracowaniu wpisują się w nurt badań partycypacyjnych². Ten rodzaj podejścia eksploracyjnego ma wymiar emancypacyjny, podkreślający podmiotowość uczestników, ich otwartość i samostanowienie. Ba-

2 Początek badań partycypacyjnych łączy się z pracami Kurta Lewina (1946), związanego ze szkołą frankfurcką oraz badaniami stosowanymi, prowadzonymi w Instytucie Tavistok. Do rozwoju badań przyczyniły się również prace Paula Freirego (1974), brazylijskiego pedagoga i zwolennika dialogowych metod badawczych oraz kolumbijskiego socjologa Orlando Fals Borda (2006), krytykującego monopolizację wiedzy, a także prace Johna Herona i Petera Reasona, które powstawały już od lat 70. ubiegłego wieku, choć autorzy ci najbardziej znani są z dużo późniejszego artykułu, który może być uznany za ich metodologiczny manifest (Heron, Reason 2001, za: Bielecka-Prus 2013). 
dani byli nie tylko partnerami w dialogu, ale także mieli wpływ na jego przebiegstawiali pytania badaczowi, wybierali miejsce, czas, wydarzenie, od którego zaczynali wywiad, kończyli spotkanie w odpowiednim dla siebie momencie.

Poddano analizie wywiady pogłębione przeprowadzone z 13 kobietami i 14 mężczyznami z NI (24 - w stopniu umiarkowanym, 3 - w stopniu znacznym), w wieku od 21 do 36 lat, zamieszkałymi w dużym mieście, z których dziewięć (4 kobiety, 5 mężczyzn) uczęszczało do warsztatu terapii zajęciowej (WTZ), dziewięć (4 kobiet i 5 mężczyzn) pracowało w zakładzie aktywności zawodowej (ZAZ) i dziewięć (5 kobiet i 4 mężczyzn) pracowało na otwartym rynku pracy (zatrudnienie wspomagane $z$ trenerem pracy). Tylko jedna osoba, 33-letni mężczyzna, mieszkała poza domem rodzinnymi, razem ze swoją dziewczyną prowadzili gospodarstwo domowe, pozostali uczestnicy badań żyli wspólnie ze swoimi rodzicami, w tym ośmiu z jednym rodzicem, jeden w rodzinie zastępczej pełnej. Badani mieli rozwinięte umiejętności komunikacyjne, trzy osoby ze znacznym stopniem NI (orzeczenie z okresu szkolnego) zniekształcały wymowę, miały problem z odmianą, posługiwały się prostą formą wypowiedzi. Tylko dwie osoby były ubezwłasnowolnione całkowicie, ich rodzice wyrazili zgodę na wywiady. Rekrutacja respondentów miała charakter stopniowy: na początku brałam udział w spotkaniach grupy wsparcia dla osób pracujących w ZAZ i na otwartym rynku oraz uczestnikami pracowni przygotowania zawodowego w WTZ, na których przedstawiłam swój projekt badawczy i zachęciłam do wzięcia w nim udziału, zgłosiło się kilka osób, potem okazało się, że pierwsi uczestnicy wywiadów zachęcili swoich kolegów i koleżanki do spotkania. Każdy respondent był zapewniony o anonimowości badań oraz o możliwości zrezygnowania z udziału w nich w każdym momencie. Projekt był realizowany w latach 2012-2015.

Usytuowanie badań w paradygmacie interpretatywno-konstruktywistycznym dało asumpt do zrozumienia toczących się dwóch konstrukcji wypowiedzi: opowieści badanych oraz opracowania podsumowującego analizę materiału badawczego. Także interpretacja odnosi się do obu podmiotów uczestniczących w badaniach. Opowieści badanych są bowiem ich interpretacją faktów z życia, zdarzeń, ale też codziennych działań, przemyśleń, planów oraz nadawaniem im znaczeń. Drugi poziom interpretacji dotyczy osoby badacza, który postępując zgodnie z obraną strategią (tu: konstruktywistyczną teorią ugruntowaną), dokonuje analizy zebranego materiału przez porównywania jednostkowych opowieści, namysłu nad ich podobieństwem i różnicami, a następnie odnosi swoje spostrzeżenia do kontekstu (społecznego i osobistego) doświadczeń życiowych respondentów. Badacz dokonuje zatem własnej interpretacji zebranych danych, która ma charakter teoretyczny, gdyż nie prowadzi do dokładnego odzwierciedlenia świata, lecz do powstania jego interpretacyjnego obrazu. Konstruowana teoria odzwierciedla ukryte znaczenia wypowiedzi osób uczestniczących w bada- 
niach, ich poglądy oparte na doświadczeniu oraz ukończone teorie ugruntowane badaczy. Naukowcy odtwarzając dane budują teorię, która jest ich własną konstrukcją, jednocześnie poprzez wykorzystanie aktywnych kodów oddają słowa uczestników (por. Charmaz 2009).

W konstruktywistycznej teorii ugruntowanej zalecana jest strategia kodowania wstępnego. Kody wstępne powinny ściśle przylegać do danych, poprzez porównywanie wydarzeń tego samego rzędu wyodrębnia się słowa - pojęcia określające działania. Nie narzuca się kodów, lecz wyodrębnia z języka wywiadów (tamże).

Dzięki metodzie stałego porównywania, stanowiącej trzon analityczny, także klasycznej teorii ugruntowanej (Glaser, Strauss 2009), dochodzi się do podobieństw i różnic $\mathrm{w}$ podejmowanych działaniach, $\mathrm{w}$ toczącym się procesie, w poglądach, przekonaniach poszczególnych badanych lub w ramach jednej wypowiedzi. Czasami ta rozbieżność dotyczy tego, co badacz usłyszał i posiadanej przez niego wiedzy lub przekonań na ten określony temat. Dzięki uzyskanej perspektywie, badacz może świadomiej podchodzić do kategorii i pojęć nakładanych na dane (kodowanie), zwracając uwagę, że własny punkt widzenia jest jednym $\mathrm{z}$ wielu. Kiedy natomiast przejdzie do drugiego etapu kodowania, będzie z rozwagą dobierać kategorie czy pojęcia dyscyplinarne. (tamże)

W konstruktywistycznej teorii ugruntowanej Kathe Charmaz (2009) proponuje skoncentrowane i zogniskowane kodowanie kategorii. W prezentowanym opracowaniu wykorzystano pierwszy typ, który pozwala na wykorzystanie najczęściej występujących kodów lub tych najistotniejszych zastosowanych w kodowaniu wstępnym. Potem następuje weryfikacja tych kodów pod względem adekwatności i znaczenia analitycznego dla wnikliwej i całościowej kategoryzacji danych.

Następny poziom kodowania ma charakter teoretyczny. Badacz wchodzi $\mathrm{w}$ ten sposób w etap budowania idei i koncepcji. Innymi słowy kategorie teoretyczne określają relacje, które mogą wystąpić między kategoriami zbudowanymi podczas kodowania zogniskowanego, mają zarazem charakter integracyjny, nadają im też formę. Kategorie te mogą pomóc w odtworzeniu spójnej, analitycznej historii. (por. Charmaz 2009).

\section{Analiza i interpretacja zebranego materiału badawczego}

W prezentowanej analizie danych, na podstawie kodowania wstępnego wydarzeń, działań, refleksji, planów dostrzeżonych w zebranych wywiadach, a następnie ogniskowania tych kodów, zostały wyłonione kategorie teoretyczne, które poniżej przedstawiam. 
Określanie dorosłości i siebie jako osoby dorosłej

Wydawać by się mogło, że wskazanie wieku jest najprostszą metodą na określenia siebie dorosłym. Jednak, choć badani jednoznacznie stwierdzali, że są dorosłymi osobami, to na pytanie o fakty potwierdzające ich dorosłość podawali głównie posiadanie dowodu osobistego niektórzy opowiadali historię wyrabiania dokumentu potwierdzającego dojrzałość społeczną. Wydaje się, że respondenci uważali za bardziej przekonujące wskazanie konkretnego symbolu oznaczającego dorosłość niż podanie swojego wieku. Natomiast nikt nie wspominal, nawet dopytany, żeby uzyskanie 18 roku życia wiązało się z uroczystością, imprezą młodzieżową, czy inną ceremonią upamiętniającą ów fakt. Niektórzy - młodsi badani - napomknęli, że rodzice im kupili czy upiekli tort.

$\mathrm{W}$ odniesieniu do stosowanego wobec siebie nazewnictwa, związanego z płcią męską, badani mężczyźni, rzadko mówili o sobie "jestem mężczyzną”, owszem rozumieli i potwierdzali ów fakt, ale samo pojęcie, jako samoistna wypowiedź, nie pojawiło się w żadnym wywiadzie (!). O grupie kolegów wypowiadali się w kategorii: ,"chłopcy", ,chłopaki”, zaś o koleżankach „dziewczyny" lub - chyba żartobliwie - "baby".

Kobiety również nie rezygnowały z określenia "dziewczyna”, które przecież nie pomniejsza ich dorosłości, a jedynie stanowi odwzorowanie powszechnych wyrażeń opisujących grupy i jednostki płci żeńskiej, w różnym wieku, także dorosłe, a nawet starzejąc się kobiety. O mężczyznach, szczególnie rówieśnikach, kolegach z WTZ, czy swoich partnerach, wyrażały się "chłopak”, "chłopcy” lub kolokwialnie "chłopaki”, "faceci”, ale to nazewnictwo jest zapewne odzwierciedleniem codziennej kultury środowisk, w których przebywają.

Badane opisywały dorosłą kobietę $\mathrm{w}$ kategoriach wyglądu zewnętrznego, zarówno przy użyciu cech związanych z płcią, ale też ze strojem. Kilka rozmówczyń podkreśliło zmianę w swoim wyglądzie jako efekt dorosłości („urosły mi piersi”, "mam okres, więc jestem dorosła"). U mężczyzn nie dostrzegłam takich tendencji, zupełnie nie zwracali uwagi na trzeciorzędowe cechy płciowe - budowę ciała, zarost, owłosienie ciała, miejsc intymnych. Warte odnotowania było spostrzeżenie, że spośród 14 respondentów płci męskiej, żaden nie nosił zarostu. O typowym wyglądzie męskim (cechy płciowe, strój) nie wypowiadali się, jakby nie miało to dla nich znaczenia, albo było zbyt oczywiste, a może nie czuli się swobodnie w relacji z kobietą - badaczką (?).

\section{Opisywanie ról dorosłych kobiet i mężczyzn}

Badani najwięcej uwagi poświęcili rolom związanym z płcią. Dążenie jednostki do realizowania ról typowych dla kobiet i mężczyzn wynika ze społecznych 
norm określających dorosłość. Młodzi ludzie w procesie dojrzewania niejednokrotnie próbują kontestować stereotypowe role kobiety i mężczyzny, jednak dla osób z niepełnosprawnością intelektualną tradycyjny obraz kobiety i mężczyzny stanowi swoisty kierunkowskaz w dojrzewaniu oraz organizowaniu sobie życia wg Foucaulta: „urządzanie się w życiu” (za: Kowalik 2018: 193-195).

Badani potrafili zatem generalizować dorosłość swojej płci. Mężczyźni powoływali się zwykle na powszechny dla naszej kultury obraz dorosłego mężczyzny. Podkreślali przede wszystkim stereotypowe role męskie - głowy rodziny („mężczyzna musi zarobić na rodzinę”, ,facet ma trudniej, bo musi utrzymać żonę i dzieci”), siły męskiej („trzeba ćwiczyć, żeby mieć siłę do roboty”, „bo chłop to musi dużo harować”), dysponenta pieniędzy („najpierw, to trzeba mieć dużo kasy, żeby kupić żonie wszystko", „facet to musi mieć forsę w kieszeni”).

Kobiety łatwiej radziły sobie ze stereotypami dotyczącymi ról związanych z płcią. W ich opinii współczesna kobieta to nie tylko piastunka dzieci i strażniczka domowego ogniska, ale osoba, która „spotyka się z koleżankami na mieście”, dla której ważna jest praca dająca satysfakcję finansową i osobistą („nie chodzi o to, żeby harować dla paru złotych", "trzeba mieć parę groszy na kosmetyki i fryzjera"), zaś mężczyzna w jej życiu nie musi być mężem, może być „facetem” lub „partnerem". Ponadto młode kobiety z NI, podobnie jak ich rówieśniczki, nie odczuwają presji zamążpójścia, co ciekawe, niektóre respondentki używały określenia „singielka" rozumiejąc, że nie ma ono pejoratywnej konotacji.

Zarówno dla mężczyzn, jak i kobiet, bardzo ważna jest rola pracownika - jako stan obecny (18 osób zatrudnionych w ZAZ i na otwartym rynku pracy), ale też jako cel życiowy (9 uczestników i uczestniczek WTZ).

Dla grupy oczekującej na pracę liczą się: charakter pracy, zarobki, środowisko pracy, czyli wszystkie atuty zatrudnienia. Młodsi badani chcieliby „przede wszystkim pracować, żeby być kimś ważnym i mieć swoje pieniądze". Jedna z kobiet pracująca w ZAZ bardzo dojrzale stwierdziła: „pracuję, żeby być pożytecznym człowiekiem". Niewiele osób natomiast postrzegało pracę jako aktywność stwarzającą możliwości rozwoju, jednak warto przytoczyć przykładowe wypowiedzi wskazujące na refleksyjny namysł ich autorek nad wartością pracy: „Żyję, pracuję, rozwijam się, doświadczam i to jest najważniejsze, to że ja nie tracę nigdy nadziei” (wypowiedź 28-letniej kobiety); „Po sobie jak patrzę, otwarta jestem bardziej do ludzi, rozmowna, klienci do mnie przychodzą na dział, pytają się, wiem co pokazać, to taki człowiek jest troszkę rozgarnięty... już się tak trochę rozkręciłam... dzięki tej pracy mam lepszy kontakt z ludźmi, rozmowę poprowadzić z kimkolwiek umiem..." (wypowiedź 30-letniej kobiety).

Choć badane osoby pracujące, skupiły się w swoich opowieściach głównie na obiektywnych atutach pracy, gdyż już sama możliwość podjęcia i trwania zatrudnienia jest dużym osiągnięciem, to część z nich odczuwa jednak pozytywne zmia- 
ny w swoim życiu. Subiektywne odczucia zachodzących procesów świadczą o większej dojrzałości niewielkiej grupy pracujących respondentów. Także z innych badań wynika, że dzięki zatrudnieniu, szczególnie w zróżnicowanym środowisku pracy, u osób z NI następuje rozwój w każdym wymiarze codziennego funkcjonowania. Między innymi, dostrzegają pozytywne i negatywne strony zatrudnienia, odnosząc się do swoich osobistych doświadczeń, stają się bardziej krytyczne, ale też rozumieją dylematy swoich pracujących rodziców, czy innych bliskich (zob. Lysaght $i$ in. 2009, Nota i in. 2010, Test i in. 2000).

Planowanie swojej przyszłości w oparciu o wizję dorosłego życia

Planowanie przyszłości przez badanych zależało od ich obecnego usytuowania. Osoby już pracujące (9 kobiet i 9 mężczyzn) opierały swoje dalsze losy na dokonaniach zawodowych. Najważniejsze jest dla nich utrzymanie pracy, niektórzy chcieli zmiany na lepiej płatne stanowisko (przykładowa wypowiedź 28-letniego pracownika KFC ,ja pytałem szefa, czy mogę przejść do obsługi klientów, powiedział, że na razie nie ma dla mnie miejsca, ale może za jakiś czas") lub takie, które dawałoby większą satysfakcję (przykładowa wypowiedź 30-letniego pracownika w ZAZ: ,ja to chciałem dostać pracę na komputerze, ale to było tylko dla tych na wózkach, jestem w gastronomii, ale to nie jest to co mi się podoba"). Młodzi ludzie uczęszczający do WTZ (4 mężczyzn i 5 kobiet, w wieku do 28 lat) chcieliby pracować, ale spośród 3 mężczyzn i 2 kobiet (z tej grupy), którzy mieli możliwość podjęcia praktyk w zakładach na otwartym rynku pracy, nikt nie czuł się jeszcze gotowy do podjęcia pracy. Starsi uczestnicy WTZ (1 mężczyzna i 3 kobiety), choć już mają za sobą serię próbek pracy (również w ramach praktyk z ramienia WTZ), nie odczuwają potrzeby pracy, zgłaszają liczne problemy, które uniemożliwiają im start zawodowy:

- ze strony rodziny, np. „Teraz już nie mogę pójść do pracy. Moja mama zmarła i muszę opiekować się tatą i prowadzić dom, bo tato choruje" (wypowiedź 35letniej kobiety);

- z powodu lęku przed utratą renty/zasiłku np. „wolę nie zaczynać pracować, wtedy stracę rentę, a jak mnie wyrzucą z pracy, to nie będzie żadnych pieniędzy" (wypowiedź 37-letniej kobiety);

- w związku z brakiem wiary we własne możliwości np. „lepiej nie, nie umiem pracować" (wypowiedź 36-letniej kobiety);

- na skutek odczuwanych trudności np. ,ja mam takie ruchy ciała, które utrudniają mi pracę, jakbym miał nieść garnek, albo coś innego np. gorącego, to mógłbym wylać, oparzyć się" (wypowiedź 35-letniego mężczyzny). 
Drugim ważnym obszarem snucia planów na przyszłość były relacje międzyludzkie. Badani mieli różne oczekiwania wobec tej sfery życia, a zależały one od ich dotychczasowych doświadczeń (zob. Arias i in. 2009; Brzezińska i in. 2011).

Młodzi mężczyźni (23-25 lat), nawet jeśli byli w związku, to miał on charakter przelotny („tak właściwie, to ona nie jest moją dziewczyną, tylko na razie tak się spotykamy, zobaczymy”), nietrwały („ona wyjechała i wszystko się skończyło... Nie ma listów, nie ma telefonów, czasami na facebooku ją widzę"), utrudniający życie (,ona ciągle mi truje, żebyśmy gdzieś razem poszli, a ja nie mam czasu, ...tyle jest zajęć”), albo luźny („my się spotykamy, ale tylko tu w ośrodku, tak jak moi koledzy, ale to nie jest na poważnie, ...jestem jeszcze za młody").

Tylko trzech mężczyzn (około 30-letnich) określiło swój związek z kobietą jako trwały. Dwóch z nich planowało wspólną przyszłość ze swoją wybranką, zaś jeden, choć był w związku ze swoją dziewczyną już od kilku lat, to stwierdził: „tak jest dobrze, ona mnie odwiedza, a ja czasami do niej na kawę przyjeżdżam, ...lubię się spotykać, to do rynku pójdziemy, to do kina, dalej to zobaczymy". We wszystkich trzech przypadkach rodzice są przychylni takim relacjom, choć o przejściu swoich synów na kolejny etap w związku (małżeństwo, wspólne zamieszkanie) - zdaniem badanych - nie chcą "pozwolić”.

Z kolei kilku ponad 30-letnich mężczyzn, $\mathrm{w}$ tym trzech po przykrych doświadczeniach (zerwanie pod wpływem nacisków rodziców, zdrady, czy prozaicznego stanu braku emocji - „nie mam już uczuć do niej”), nie dążą do nowego związku, albo w ogóle do "bycia z kobietą", gdyż porażka była zbyt trudna - „to przez jej matkę rozeszliśmy się. Wysyłała mnie do lekarza (seksuologa), żebym opowiadał różne takie rzeczy, a ja się wstydziłem. W ogóle nie chcę tak" (z wypowiedzi 32-letniego mężczyzny), albo trudno jest im zabiegać o względy płci przeciwnej, gdy się ma ponad 34-lata i brakuje młodzieńczych doświadczeń w „byciu parą". Można było odnieść wrażenie, że badani (niezależnie od wieku), którzy nie byli w związku (z różnych powodów), próbowali tłumaczyć ten stan swoim zaangażowaniem w różne aktywności, które dawały im satysfakcję (,ja mam tylko pracę i kolegę. Dziewczyny nie są mi potrzebne" - wypowiedź 33-letniego mężczyzny; „ja trenuję podnoszenie ciężarów i mam już sukcesy, nie mam czasu na dziewczyny" - wypowiedź 26-letniego mężczyzny).

Większość badanych żyje z dnia na dzień, nawet jeśli snują plany na przyszłość, czy te związane z pracą, czy z budowaniem bliższych związków $\mathrm{z}$ drugą osobą, to $\mathrm{w}$ ich wypowiedziach odczuwało się niepewność, brak wiary, lęk; część artykułowała zależność swojej przyszłości od decyzji rodziców - „mama mi kazała”, od potoczenia się losu - „jjakoś to będzie”. Dało się odczuć, że sami nie są w stanie zrealizować swoich marzeń, czy planów, dodać należy, że rzadko były to zamierzenia odrealnione, pozbawione sensu, czy infantylne. Artykułowany przez badanych brak gotowości do realizacji pewnych wyzwań dorosłości wyni- 
kał z dotychczasowych doświadczeń, jak w przypadku 28-letniej kobiety: „ja wiem, że nie mogę mieć dzieci, to znaczy może mogłabym, ale nie poradziłabym sobie z nimi, jak ja nie umiem opiekować się dziećmi mojego brata, które mają 8 lat - bratanek i 5 lat - bratanica, po prostu nie radzę sobie z nimi" lub jak w przypadku 24-letniego mężczyzny: „jak ja mam wiedzieć, jak to jest w związku, jak ja się jeszcze nawet z dziewczyną nie całowałem... Już myślałem, że znalazłem tą jedyną, ale okazało się, że ona teraz jest zajęta (ma chłopaka), to co mam robić, czekać na nią czy szukać innej?".

\section{Samodzielność i odpowiedzialność jako wyzwania dorosłości}

Samodzielność jako przedpole autonomii jest obszarem funkcjonowania osoby z NI, który do niedawna był pod władzą nadopiekuńczych rodziców, nauczycieli, wychowawców. Jednak od ok. dwóch dekad obserwuje się zmianę świadomości, nie tylko terapeutów i trenerów pracujących z dorosłymi osobami z NI, ale także ich rodziców, wynikającą z coraz większej społecznej akceptacji tej populacji, dostrzegania jej potencjału, a nie tylko ograniczeń, traktowania jako pełnoprawnych obywateli (szczególny udział w tej zmianie ma podpisanie w 2012 r. przez Polskę Konwencji o prawach osób niepełnosprawnych). Usamodzielnianie osoby z NI na każdym etapie życia stało się wyzwaniem dla środowisk socjalizacji pierwotnej (rodzina) i wtórnej (przedszkole, szkoła, ośrodki, WTZ itp.).

Badane osoby akcentowały samodzielność jako atrybutu dorosłości w ogóle, ale przede wszystkim swojej. $Z$ dumą opowiadały o swoich osiągnięciach $w$ tym zakresie. Większość z nich porusza się swobodnie po mieście. Osoby pracujące traktowały ten rodzaj niezależności jako oczywisty - „przecież do pracy mnie nikt nie będzie woził". Zwykle trener pracy analizuje ze swoim klientem przebieg trasy z domu do pracy i odwrotnie, pokonują ją razem, ustalają środki transportu, jednak warunkiem jest zdobyta już wcześniej samodzielność.

Osoby uczęszczające do WTZ miały w tym zakresie różny poziom umiejętności. Większość, wraz z upływem czasu, nabierała pewności i, jeśli otrzymała pozytywne wzmocnienie ze strony rodziny, zaczynała poruszać się samodzielnie, zresztą to jeden z celów rehabilitacji stawianych w WTZ. Kilka osób było dowożonych do warsztatu, najczęściej z powodu sprzężenia niepełnosprawności intelektualnej z ruchową, zmysłową lub zdrowotną.

Badani określali własną samodzielność także w odniesieniu do obowiązków domowych. Zróżnicowanie było spore, jednak każdy z nich miał powierzone zadania: sprzątanie, odkurzanie, wychodzenie z psem, koszenie trawy, pieczenie, gotowanie.

Z kolei o innych ważnych cechach dorosłego człowieka, takich jak, odpowiedzialność i samostanowienie (decydowanie o sobie i podejmowanie decyzji), re- 
spondenci nie wypowiadali się w sposób dosłowny. Są to pojęcia abstrakcyjne, więc jedynie przytaczane fakty wskazują na ich pokłady odpowiedzialności i samostanowienia: 32-letnia kobieta bardzo chciała opiekować się swoją chorującą matką, na co środowisko i sama zainteresowana jej nie pozwolili, bo przecież to ona musi być pod opieką - „mama jest dla mnie wszystkim, to moje kochanie, teraz choruje na serce. $W$ pracy zasłabła $i$ trafiła do szpitala, ale mi nic nie powiedzieli. Teraz jest $\mathrm{w}$ domu i ciocia się nią zajmuje, a przecież ja też potrafię, a ona mówi, że to mną się trzeba opiekować"; 22-letni mężczyzna zaprzestał uczęszczania do warsztatu terapii zajęciowej z powodu konieczności podjęcia opieki nad obłożnie chorym dziadkiem w czasie nieobecności pracujących rodziców, co trwało ponad rok - „karmiłem dziadka, siedziałem przy nim, jak chciał coś powiedzieć, a nie mógł mówić, to rysował albo pisał"; z kolei 28-letnia kobieta opowiedziała historię swojej niefrasobliwości w korzystaniu z karty kredytowej, którą przysłano z banku, a ona samodzielnie ją uruchomiła - „no i straciłam wszystkie pieniądze, a to na aparat fotograficzny, który mi skradziono, a to na inne bzdury. Tato jak się dowiedział, to był zły. Poszliśmy do banku i tam powiedzieli, że będę w ratach spłacać. Już tylko trzy miesiące zostało, to wszystko z mojego konta. Zasiłek zostaje, a pensja cała idzie na spłatę. Mam nauczkę, już żadnych listów z banku nie będę otwierać."

Osoby pracujące wiele miejsca w swoich opowieściach poświęciły czynnościom zawodowym oraz swojej roli na stanowisku pracy: „Ja przygotowuję taką amerykańską surówkę Kolesław. Moja praca polega na tym, że nastawiam daty i godziny, w skrzynkach się mieści po 24 sztuki, do tego mi jest łyżka potrzebna, garnek, metkownica, skrzynki, wieczka, pudełka..." (z wypowiedzi 32-letniej kobiety). „To jest taka przyprawa, taka albo pikantna, albo łagodna i ja przykrywam nią kurczaka na 10 min, zalewam zimną wodą, przykrywam i to się kręci przez 10 min i to opisuję na 48 godzin, na dwa dni, no i te kurczaki, przechodzą tą przyprawą, tak i idą do chłodni" (z wypowiedzi 28-letniego mężczyzny). Wszyscy pracujący uczestnicy badań z zaangażowaniem poruszali temat obowiązków zawodowych, wypowiadali się z powagą, rozumieli, że podejmują odpowiedzialność za powierzone działania. Każde niepowodzenie na stanowisku pracy odbierali jako osobistą porażkę, która utrwala wizerunek ich niepełnosprawności w odbiorze społecznym. Jeden z respondentów (33-letni mężczyzna) ujął to tak: „nie możemy mówić, że czegoś nie umiemy, że nam nie wychodzi, bo będzie jeszcze gorzej, powiedzą, że to przez to, że jesteśmy niepełnosprawni, to sobie nie radzimy". Kilku badanych zwróciło uwagę na taką zależność, szczególnie przejmujące były słowa 34-letniej kobiety ze znaczną niepełnosprawnością intelektualną, pracującej w ZAZ: „duża ta podłoga, brudna, bolą plecy, a kucharka - jeszcze raz myj, bo brudno - ja się boję, zamykam oczy, tylko nie płakać, i dalej myję..." 


\section{Ograniczanie i wspieranie w dorosłości}

Dla respondentów opinia terapeutów zajęciowych, trenerów, czy innych opiekunów jest niezwykle ważna i w różnych momentach wywiadów powoływali się na wypowiedzi osób znaczących. Na pytanie: kto potwierdza, że są dorośli, odpowiadali, głównie kobiety, że „tutaj w warsztacie terapeuci mówią nam, że jesteśmy dorośli”. Nie utwierdzają ich w tym rodzice, tylko „czasami, jak muszę coś zrobić, to wtedy mama mówi, że już jestem dorosła” lub „tato mówi, że jestem już na tyle dorosły, że mogę kosić trawę".

Badani mężczyźni rzadko powoływali się na opinię bliskich sobie osób w potwierdzaniu swojej dorosłości. Praktyka wychowywania dorastających chłopców dowodzi, że upomina się ich, wtedy gdy nie mogą z czymś sobie poradzić, gdy zadanie przerasta ich możliwości, przypominając, że mają zachowywać się jak mężczyźni, że są dorośli (prawie dorośli). Również z tych powodów mężczyznom z NI trudniej przychodzi utwierdzanie innych, ale też samych siebie, że są dorośli. Zauważyć można ich konsternację w okazywaniu swojej dorosłości, jakby brakowało im atutów, nie tylko tych zewnętrznych, ale szczególnie tych wynikających z ról dorosłych mężczyzn.

Niewątpliwie rodzice są ważni dla badanych kobiet i mężczyzn, stanowią oparcie i punkt odniesienia. Także w swoich narracjach uczestnicy badań poświęcali im dużo uwagi, często powoływali się na ich zdanie, przejmowali ich sposób myślenia o poruszanym temacie. Rzadko natomiast respondenci wskazywali rodziców jako podmioty, które wspomagają ich w dążeniu ku dorosłości. Owszem rodzice nauczyli ich wiele - od dbania o higienę po umiejętności bardziej złożone, jak gotowanie, czy robienie zakupów - jednak z wypowiedzi wyłaniał się obraz matek i ojców, którzy przez nakazy, zakazy i system wzmocnień negatywnych sprawują kontrolę nad swoimi dorosłymi dziećmi. Za przykład niech posłużą następujące wypowiedzi:

„Ja pojechałam do mojej koleżanki na urodziny, zapytałam się ojca, ja się mu postawiłam, bo chciałam zostać na noc... to się mu po prostu postawiłam ... dla mnie to teraz nie jest przyjemne mieszkać z tatą, bo on się ciągle na mnie wyżywa i w ogóle... on ma problemy ze sobą, on ma klapki na oczach, on nie widzi nikogo innego poza swoim czubkiem nosa, on tylko myśli, że wszystko jest ok., a tu nic nie jest ok. nic, ja po prostu, ja tam już nie wytrzymuję" (wypowiedź 26-letniej kobiety).

„Po prostu ją informuję, że będę później, żeby się nie martwiła i nie wydzwaniała ... To mnie czasami denerwuje, bo wie gdzie idę, wie, o której będę, a jeszcze karze dzwonić ... No, już ile mogę tego słuchać..." (wypowiedź 25-letniego mężczyzny). 
Dla osób zatrudnionych na otwartym rynku pracy ważną postacią jest trener pracy, dlatego poświęciły jej wiele uwagi³ Jest ważny, gdyż przygotowuje do pracy: „...on mnie szkoli, znaczy douczali, nie mogłem się odnaleźć w sobie...", ale też są wspierającymi mentorami: „po prostu do A... (trenerka) przychodzimy no, żeby coś podyskutować porozmawiać... no czasami są problemy, jest czasami dużo pracy...". Trenerzy pracy organizują też grupę wsparcia dla pracujących osób z NI: „lubię tam przychodzić, rozmawiamy o różnych problemach w pracy, uczymy się co jest ważne w pracy" (z wypowiedzi 23-letniej kobiety zatrudnionej na otwartym rynku).

\section{Konkluzje}

Osoby z głębszą NI (w stopniu umiarkowanym lub znacznym) opisując dorosłość sięgają po obiektywne, społecznie zweryfikowane wyznaczniki tego stanu. Potrafią generalizować pojęcie dorosłości oraz odnieść je do swojej sytuacji. Zdecydowanie trudniej im przychodzi subiektywne rozumienie swojej dorosłości, które wiąże się z wewnętrznym poczuciem dojrzałości, a wyraża się świadomym planowaniem przyszłości, gotowością do podejmowania odpowiedzialności, samostanowieniem. (por. Brzezińska i in. 2011; Kijak 2017; Mill i in. 2010; Pisula 2008;) Z wymienionych powodów łatwiej przychodziło badanym wypowiadanie się $\mathrm{w}$ kwestiach dotyczących dorosłości $\mathrm{w}$ wymiarze społecznym, niż jednostkowym - własnym. Co wyraźnie zaznaczało się w trakcie wywiadów.

Ponadto należy podkreślić pewną konstatację: choć badane osoby lokowały wśród atrybutów dorosłości pełnienie ról typowych dla kobiet i dla mężczyzn, to jednak dostrzegały swoje ograniczenia w tym zakresie (zob. Cytowska 2012; Lachapelle i in. 2005; Nota i in. 2007); niektórzy powoływali się na swoje doświadczenia, inni wyrażali swoje obawy w powiązaniu z opinią swoich bliskich (zob. Suwalska-Barancewicz, Malina 2013). Ostrożnie też formułowali deklaracje w realizowaniu typowych dla dorosłych ludzi planów na przyszłość. (por. Brown i in. 2009; Żyta 2011) Można rzec, że zostali nauczeni owej ostrożności, poddając się władzy tych co lepiej wiedzą i chcą ich ochronić, więc ograniczają im możliwość zmierzenia się z realnymi wyzwaniami, doświadczanie błędów i porażek (por. Brzezińska i in. 2011; Mill i in. 2010; Pisula 2008).

3 Rola trenera pracy polega na: wspólnym z klientem wyszukaniu odpowiedniego miejsca pracy, opracowaniu systemu uczenia go czynności zawodowych (dlatego trener sam musi przepracować te czynności na stanowisku), uczeniu i ćwiczeniu wykonywania zadań pracowniczych - etap po etapie - wspólnie pracując ze swoim podopiecznym na stanowisku pracy. Ponadto trener wspiera go w nawiązywaniu relacji i interakcji w miejscu zatrudnienia, uczy rozwiązywania problemów, które mogą wyniknąć w czasie godzin pracy. Pomaga też współpracownikom zrozumieć specyficzne zachowania czy reakcje niepełnosprawnego pracownika. 
Podsumowując zaprezentowaną analizę, chciałabym podkreślić, że osoby z głębszą NI kreują dorosłość na podstawie wzorów osobowych typowych dla kultury, w której są socjalizowani. Łatwo ulegają autorytetom, więc od postaw znaczących Innych zależy, jak będą przygotowywani do dorosłości i jak będzie ten proces przebiegał (por. Krzemińska, Lindyberg 2012). W ich wypowiedziach dorosłość jawi się jako zbiór pewnych kompetencji, które trzeba zdobyć i celów, które trzeba zrealizować. Stąd wydaje się, że dominuje u nich postrzeganie dorosłości w wymiarze obiektywnym. Subiektywne przemyślenia o dorosłości jako dojrzałości emocjonalnej, moralnej, osobowościowej pojawiają się rzadko (por. Brzezińska i in. 2011; Rękosiewicz 2012). Jednak pomijając słabą zdolność do abstrahowania, już w konkretnych wypowiedziach respondentów można było zauważyć ich wyłaniającą się dojrzałość, mądrość życiową - zatem im więcej zdobędą doświadczenia, tym bardziej będą dojrzali.

\section{Bibliografia}

Arias B., Ovejero A., Morentin R. (2009), Love and Emotional Well-being in People with Intellectual Disabilities, Spanish Journal of Psychology, 12, 1, 204-216.

Bielecka-Prus J. (2013), Paradygmat partycypacyjny w naukach społecznych. Wykorzystywanie danych wytworzonych przez badanych w analizie jakościowej, Rocznik Lubuski, 39, 29-51.

Brzezińska A., I., Kaczan R., Piotrowski K., Rękosiewicz M. (2011), Odroczona dorosłość: fakt czy artefakt?, Nauka, 4, 67-107.

Brown R.I., Schalock R.L., Brown I. (2009), Quality of life: Its application to persons with intellectual disabilities and their framilies - Introduction and overview, Journal of Policy and Practice in Intellectual Disabilities, 6, 2-6.

Charmaz K. (2009), Teoria ugruntowana: Praktyczny przewodnik po analizie jakościowej, tłum. B. Komorowska, PWN, Warszawa.

Cytowska B. (2012), Trudne drogi adaptacji: wattki emancypacyjne w analizie sytuacji dorostych osób z niepełnosprawnościq intelektualną we wspótczesnym społeczeństwie polskim, Oficyna Wydawnicza „Impuls”, Kraków.

Cytowska B., Wołowicz-Ruszkowska A. (2013), Trener pracy: dokument uwzględniajacy wiedze zastana na temat funkcjonowania trenera pracy, na podstawie polskich i zagranicznych opracowań, Polskie Forum Osób Niepełnosprawnych, Warszawa.

Dubas E. (2005), Andragogiczne poszukiwania rozumienia dorostości [w:] Człowiek dorosty - istota (nie) znana?, E. Dubas (red.), Wydawnictwo NOVUM, Łódź-Płock, 133-149.

Gąciarz B. (2017), Między deklaracjami równego traktowania a realiami wykluczenia. Polityka wobec niepetnosprawności jako przejaw dysfunkcji sfery publicznej, Studia Socjologiczne, 4, 95-118.

Glanc Z. (2011), Obraz dorosłości w dobie ponowoczesnej. Mozaika wymiarów dorosłości, Edukacja Dorosłych, 1, 115-132.

Glaser B.G., Strauss A.L. (2009), Odkrywanie teorii ugruntowanej. Strategie badania jakościowego, przeł. M. Gorzko, Wydawnictwo Nomos, Kraków. 
Głodkowska J. (2014), Być podmiotem i stawać się autorem swojego życia-paradygmat wsparcia w przygotowaniu osób z niepetnosprawnością do budowania własnej tożsamości i wzbogacania dobrostanu, Człowiek-Niepełnosprawność-Społeczeństwo, 4, 9-44.

Gołubiew-Konieczna M. (2016), Wspieranie osób z głębszą i głębokq niepetnosprawnościa intelektualna i ich rodziców w drodze przez całe życie na przykładzie działalności Polskiego Stowarzyszenia na rzecz Osób z Upośledzeniem Umysłowym, koło w Gdańsku, Niepełnosprawność. Dyskursy Pedagogiki Specjalnej, 24, 169-182.

Kijak R. (2017), Dorośli z głębsza niepetnosprawnościa intelektualna jako partnerzy, matżonkowie i rodzice, Oficyna Wydawnicza „Impuls”, Kraków.

Kowalik S. (2018), Stosowana psychologia rehabilitacji, t. 17, Wydawnictwo Naukowe Scholar, Warszawa.

Krzemińska D., Lindynberg I. (2012), Wokót dorosłości osób z niepetnosprawnością intelektualną. Teksty rozproszone, Oficyna Wydawnicza „Impuls”, Kraków.

Lachapelle Y., Wehmeyer M.L., Haelewyck M.C., Courbois Y., Keith K.D., Schalock R., Verdugo M.A., Walsh P.N. (2005), The relationship between quality of life and self-determination: an international study, Journal of Intellectual Disability Research, 49 (10), 740-744.

Lysaght R., Ouellette-Kuntz H., Morrison C. (2009), Meaning and value of productivity to adults with intellectual disabilities, Intellectual and Developmental Disabilities, 47, 413-424.

Malewski M. (2013), "Dorosłość"- kłopotliwa kategoria andragogiki, Teraźniejszość - Człowiek - Edukacja, 3 (63), 23-40.

Martin L., Ouellette-Kuntz H., McKenzie K. (2017), The Power of Population Health Data on Aging and Intellectual and Developmental Disabilities: Reactions of Knowledge Users, Jurnal of Policy and Practice in Intellectual Disabilities, 14 (4), 268-278.

Mill A., Mayes R., McConnell D. (2010), Negotiating autonomy within the family: the experiences of young adults with intellectual disabilities, British Journal of Learning Disabilities, 38, 3, 194-200.

Nota L., Ferrrari L., Soresi S., Wehmeyer M.L. (2007), Self-determination, social abilities, and the quality of life of people with intellectual disabilities, Journal of Intellectual Disability Research, 51, 850-865.

Nota L., Ginevra M. C., Carrieri L. (2010), Career interests and self-efficacy beliefs among young adults with an intellectual disability, Journal of Policy and Practice in Intellectual Disabilities, 7, 250-260.

Obiektywna i subiektywna jakość życia dorostych osób z niepetnosprawnościq intelektualnq zamieszkujacych województwo wielkopolskie. Uwarunkowania środowiskowe oraz poziom wsparcia realizatorów polityki społecznej. Raport z badań, Stowarzyszenie na Tak, http://test.rops.poznan.pl (dostęp: 04.11.2016).

Oleś P.K. (2011), Psychologia człowieka dorosłego, PWN, Warszawa.

Parchomiuk M. (2016), Seksualność człowieka z niepetnosprawnością intelektualną, Oficyna Wydawnicza „Impuls”, Kraków.

Pichalski R. (2003), Refleksje nad dorostościa [w:] Dorosłość, niepetnosprawność, czas wspótczesny. Na pograniczach pedagogiki specjalnej, K.D. Rzedziecka, A. Kobylańska (red.), Oficyna Wydawnicza „Impuls”, Kraków, 79-92. 
Pisula E. (2008), Dorosłość osób z niepetnosprawnościq intelektualnq - szanse i zagrożenia, PSOUU, DG-Graf, Warszawa.

Rękosiewicz M. (2012), W drodze do dorostości. Tożsamość osób z niepetnosprawnościa intelektualna, TIPI, Wielichowo.

Rozporządzenie MEN z dnia 9 sierpnia 2017 r. w sprawie warunków organizowania kształcenia, wychowania i opieki dla dzieci i młodzieży niepełnosprawnych, niedostosowanych społecznie i zagrożonych niedostosowaniem społecznym, Dz. U. z 2017 r., poz. 1578.

Settersten R.A., Ottusch T.M., Schneider B. (2015), Becoming Adult: Meanings of Markers to Adulthood. Emerging Trends in the Social and Behavioral Sciences: An Interdisciplinary, Searchable, and Linkable Resource, John Wiley \& Sons.

Strnadova I., Evans D. (2012), Subjective Quality of Life of Women with Intellectual Disabilities: The Role of Perceived Control over their Own Life in Self-determined Behaviour, Journal of Applied Research in Intellectual Disabilities, 25, 71-79.

Suwalska-Barancewicz D., Malina A. (2013), Stres i postawy rodzicielskie matek i ojców osób dorostych z niepetnosprawnościa intelektualna, Psychologia Rozwojowa, 18, 2.

Test D.W., Carver T., Ewers L., Haddad J., Person J. (2000), Longitudinal job satisfaction of persons in supported employment, Education and Training in Mental Retardation and Developmental Disabilities, 35, 365-373.

Tyndall B.D., Christie-Mizell C.A. (2015), Mastery, Homeownership, and Adult Roles During the Transition to Adulthood, Sociological Inquiry, 86, 1, 5-28.

Wojnarowska A. (2010), Niepetnosprawność intelektualna w publicznym i prywatnym dyskursie, Oficyna Wydawnicza „Impuls”, Kraków.

Zasępa E. (2017), Osoba z niepetnosprawnościa intelektualną. Procesy poznawcze, Oficyna Wydawnicza „Impuls”, Kraków.

Żyta A. (2011), Życie z zespołem Downa. Narracje biograficzne rodziców, rodzeństwa i dorostych osób z zespołem Downa, Oficyna Wydawnicza „Impuls”, Kraków. 